\title{
HUBUNGAN TINGKAT KECEMASAN DENGAN LAMA HARI RAWAT PADA PASIEN AKUT MIOKARD INFARK (AMI) DI RUANG ICVCU RSUD DR. MOEWARDI SURAKARTA
}

\author{
Armada Karima, Yuyun Setyorini \\ Kementerian Kesehatan Politeknik Kesehatan Surakarta Jurusan Keperawatan
}

\begin{abstract}
Myocardial Infarction, Anxiety, Length of Stay. The purpose of nursing care of cardiovascular patients are to repair hemodynamic, to suffice oxygen need and to decrease anxiety. AMI patients who are undergoing treatment can use anxiety and may the length of stay. Research purpose to determine the relationship between the anxiety and length of stay in myocardial infarction patients at ICVCU Dr. Moewardi General Hospital. This study is descriptive analytic correlation using cross sectional approach. The subject is all AMI patients. The sampling technique using in this research is total sampling. A questionnaire was constructed to collect data. The collection data was analyzed by using spearman. Retrieved from 30 respondents, it is the average age of patients with myocardial infarction is 51-65 (63,3\%) and the majority of the majority of the male gender with percentage 63,3\%. Majority of AMI patients moderate anxiety with percentage $43,3 \%$ and long of stay fast with a percentage 56,7\%. Analysis of test result obtained probality value 0.41. Based on the analysis it can be concluced that there is a significant relationship between anxiety and length of day in myocardial infarction patient at ICVCU Dr. Moewardi General Hospital Surakarta.
\end{abstract}

Keywords : Myocardial Infarction, Anxiety, Length of Stay

\begin{abstract}
Abstrak: Infark miokard, Kecemasan, Lama Tinggal. Tujuan asuhan keperawatan pasien kardiovaskular adalah untuk memperbaiki hemodinamik, untuk mencukupi kebutuhan oksigen dan mengurangi kecemasan. Pasien AMI yang sedang menjalani perawatan bisa menggunakan kecemasan dan mungkin lamanya tinggal. Tujuan penelitian untuk mengetahui hubungan antara kecemasan dan lama tinggal pada pasien infark miokard di Rumah Sakit Umum ICVCU Dr. Moewardi. Penelitian ini merupakan penelitian deskriptif analitik dengan pendekatan cross sectional. Subjeknya adalah semua pasien AMI. Teknik sampling yang digunakan dalam penelitian ini adalah total sampling. Kuesioner dibuat untuk mengumpulkan data. Data koleksi dianalisis dengan menggunakan spearman. Diperoleh dari 30 responden, rata-rata usia penderita infark miokard adalah 51-65 (63,3\%) dan mayoritas mayoritas jenis kelamin laki-laki dengan persentase $63,3 \%$. Mayoritas pasien AMI mengalami kecemasan moderat dengan persentase $43,3 \%$ dan lama tinggal cepat dengan persentase $56,7 \%$. Analisis hasil uji diperoleh nilai probabilitas 0,41. Berdasarkan hasil analisis dapat disimpulkan bahwa ada hubungan yang signifikan antara kecemasan dan lamanya hari pada pasien infark miokard di ICVCU Rumah Sakit Umum Dr. Moewardi Surakarta.
\end{abstract}

Kata Kunci: Infark Miokard, Kecemasan, Lama Tinggal 


\section{PENDAHULUAN}

Penyakit jantung merupakan sosok penyaki yang menakutkan dan masih menjadi masalah yang serius baik di negara maju maupun berkembang. Seiring dengan perubahan pola hidup masyarakat, angka kematian akibat penyakit kardiovaskuler di Indonesia mengalami peningkatan yang signifikan yaitu diperkirakan mencapai $43,5 \%$ per 100.000 penduduk negara kita (Depkes, 2011).

Jumlah kasus penyakit jantung di Jawa Tengah pada tahun 2007 sebanyak 29.099 kasus, pada tahun 2008 sebanyak 29.933 kasus, pada tahun 2009 sebanyak 24.031 kasus dan dan pada tahun 2011 sebanyak 35.35.707 kasus (Tsani, 2013). Berdasarkan data yang diperoleh dari rekam medik RSUD Dr. Moewardi Surakarta diperoleh data prevalensi penderita akut miokard infark di ruang ICVCU pada tahun 2013 sebanyak 183 pasien, sedangkan pada tahun 2014 meningkat menjadi 292 pasien, dan tahun 2015 meningkat menjadi 325 pasien. Berdasarkan hasil studi pendahuluan pasien yang dirawat diruang ICVCU RSUD Dr. Moewardi selama 2 minggu yaitu tanggal 30 November sampai 13 Desember 2015 terdapat 20 pasien dengan akut miokard infark (Rekam Medis Dr. Moewardi 2015).

Perawatan pasien pada penyakit kardiovaskuler secara umum bertujuan untuk memperbaiki hemodinamik, mengurangi kecemasan, meningkatkan konsep diri, menghilangkan rasa nyeri, mencukupi kebutuhan oksigen, menjaga kenormalan pola eliminasi dan mencegah kematian (Brunner \& Suddart, 2002), selanjutnya dengan tercapainya tujuan perawatan kardiovaskuler akan dapat memperpendek lama hari rawat pada pasien akut miokard infark.

Dampak psikologis terhadap sering kali membuat pasien merasa cemas. Kecemasan sangat berkaitan dengan perasaan tidak pasti dan tidak berdaya, keadaan emosi ini tidak memiliki obyek yang spesifik. Kecemasan bebeda dengan rasa takut, yang merupakan penilaian intelektual terhadap suatu yang berbahaya. Kecemasan juga akan berdampak pada fisiologis dan psikologis. Secara fisiologis akan mengakibatkan jantung berdebar, palpitasi, tekanan darah meningkat kadang juga menurun, nafas cepat dan dangkal, dan secara psikologis akan mengakibatkan kegelisahan, disorientasi, dan penurunan konsentrasi (Stuart \& Sundeen, 2002).

Selama observasi di Ruang ICVCU RSUD Dr. Moewardi Surakarta penulis mengamati fenoma yang ada di ruangan antara lain angka kematian yang tinggi, gangguan tidur, dan kecemasan pasien di ruangan tersebut. Saat melakukan observasi dari 9 pasien, 4 pasien mengalami gangguan tidur, sulit untuk tidur, nafsu makan menurun, merasa takut jika ditinggal sendirian, pasien meminta untuk didampingi oleh keluarga sebelum jam kunjungan ruangan, dan pasien kadangkadang menghela nafas panjang, 4 dari 9 pasien tersebut mengalami tanda dan gejala kecemasan. Penulis ingin mengkaji lebih lanjut permasalahan kecemasan di ruangan tersebut, apakah rata-rata pasien cemasnya meningkat karena lama hari rawat atau faktor lain.

\section{METODE PENELITIAN}

Penelitian ini adalah jenis penelitian ini non eksperimen : deskriptif analitik korelasi dengan 
menggunakan desain penelitian cross sectional.

Penelitian ini dilakukan di ruang ICVCU RSUD Dr. Moewardi. Waktu penelitian pada bulan Maret Mei 2016. Populasi dalam penelitian ini adalah seluruh pasien infark miokard akut yang dirawat di ruang ICVCU RSUD Dr. Moewardi. Teknik pengambilan sampel menggunakan teknik total sampling. Jumlah sampel dalam penelitian ini adalah 30 responden yang memenuhi kriteria inklusi. Penelitian ini menggunakan instrumen penelitian kuesioner.

\section{HASIL PENELITIAN}

Dari sejumlah 30 responden didapatkan mayoritas berjenis kelamin laki-laki sebanyak 19 responden (63.3\%), sedangkan yang berjenis kelamin perempuan sebanyak 11 responden (36.7\%), jadi responden laki-laki lebih banyak 7 responden dari perempuan.

Mayoritas responden terdiri dari umur 50-65 tahun sebanyak 19 responden $(63,3 \%)$, kemudian umur 40-50 tahun sebanyak 9 responden $(30.0 \%)$, dan yang paling rendah umur $>66$ tahun sebanyak 2 responden $(6,7 \%)$.

Dari 30 responden yang didapatkan, mayoritas mengalami kecemasan sedang sebanyak 13 responden dengan presentase 43,3\%, 10 responden mengalami kecemasan berat dengan presentase 33,3\%, 7 responden mengalami kecemasan ringan, tidak ada responden yang mengalami tidak cemas maupun dengan kecemasan panik.

Bahwa sebagian besar responden menjalani hari rawat sedang sebanyak 17 responden (56.7), 13 responden (43.3) menjalani hari rawat cepat, dan tidak ada responden yang menjalani hari rawat lama.

Tabel 1

Distribusi Frekuensi Berdasarkan Jenis Kelamin

\begin{tabular}{ccc}
\hline Jenis Kelamin & Frekuensi & $\begin{array}{c}\text { Prosentase } \\
(\mathbf{\%})\end{array}$ \\
\hline Laki-Laki & 19 & 63,3 \\
Perempuan & 11 & 36,7 \\
\hline Total & 30 & 100 \\
\hline
\end{tabular}

Tabel 2

Distribusi Frekuensi Berdasarkan Usia

\begin{tabular}{ccc}
\hline Usia & Jumlah & $\begin{array}{c}\text { Prosentase } \\
(\mathbf{\%})\end{array}$ \\
\hline $40-50$ & 9 & 30,0 \\
$51-65$ & 19 & 63,3 \\
$>66$ & 2 & 6,7 \\
\hline Total & 30 & 100 \\
\hline
\end{tabular}

Tabel 3

Distribusi Frekuensi Berdasarkan Kecemasan

\begin{tabular}{ccc}
\hline Kecemasan & Jumlah & $\begin{array}{c}\text { Prosentase } \\
(\boldsymbol{\%})\end{array}$ \\
\hline Tidak Cemas & 0 & 0 \\
Ringan & 7 & 23,3 \\
Sedang & 13 & 43,3 \\
Berat & 10 & 33,3 \\
Panik & 0 & 0 \\
\hline Total & 30 & 100 \\
\hline
\end{tabular}

Tabel 4

Distribusi Frekuensi Berdasarkan Lama Hari Rawat

\begin{tabular}{ccc}
\hline Usia & Jumlah & $\begin{array}{c}\text { Prosentase } \\
(\boldsymbol{\%})\end{array}$ \\
\hline Cepat & 13 & 43,3 \\
Sedang & 17 & 56,7 \\
Lama & 0 & 0 \\
\hline Total & 30 & 100 \\
\hline
\end{tabular}


Tabel 5

Distribusi Frekuensi Berdasarkan Lama Hari Rawat

\begin{tabular}{|c|c|c|c|c|}
\hline & \multicolumn{3}{|c|}{ Shapiro-Wilk } & Keterangan \\
\hline & Stat & Df & Sign & \\
\hline Kecemasan & .808 & 30 & .000 & $\begin{array}{c}\text { Tidak } \\
\text { Normal }\end{array}$ \\
\hline Lama Hari Rawat & .632 & 30 & .000 & $\begin{array}{c}\text { Tidak } \\
\text { Normal }\end{array}$ \\
\hline
\end{tabular}

Tabel 6

Uji Hipotesa Kecemasan Dan Lama

\begin{tabular}{lccc}
\multicolumn{4}{c}{ Hari Rawat } \\
\hline & $\begin{array}{c}\text { Spearman } \\
\text { Correlation }\end{array}$ & $\begin{array}{l}\text { Sig. } \\
\text { (2-tailed) }\end{array}$ & $\mathrm{N}$ \\
\hline Kecemasan & 1.000 & 0.41 & 30 \\
Lama Hari & .375 & 0.41 & 30 \\
Rawat & & & \\
\hline
\end{tabular}

\section{PEMBAHASAN}

Berdasarkan hasil penelitian mayoritas responden pada penelitian ini adalah berjenis kelamin laki-laki dengan presentase $63,3 \%$ dan $36,7 \%$ dalah perempuan. Hal ini sesuai yang dikemukakan Muttaqin (2009) bahwa akut miokard infark lebih banyak terjadi pada pria dibandingkan dengan wanita, mungkin dipengaruhi oleh gaya hidup seperti stress yang tinggi, minuman keras, kebiasaan merokok yang mengakibatkan aterosklerosis sehingga meningkatkan kebutuhan oksigen. Dalam penelitian yang dilakukan oleh Yuliyanti (2012) bahwa $51,43 \%$ respondennya adalah pria, karena berkontribusi dalam memperbesar faktor resiko yaitu merokok. Selain itu laki-laki memiliki resiko 2-3 kali mengalami penyakit jantung koroner daripada perempuan sebelum menopause karena perempuan terlindungi oleh hormon esterogen yang mencegah kerusakan pembuluh darah yang berkembang menjadi proses aterosklerosis (Smeltzer \& Bare, 2002). Penelitian lain yang dilakukan oleh Maena \& Liebermen (2009) menyebutkan perempuan lebih peduli dibandingkan laki-laki tentang efek penyakit, progam terapi dan kondisi kesehatannya. Sehingga laki-laki lebih rentang mengalami serangan jantung. Teori lain menyebutkan bahwa lakilaki lebih rentan terhadap terjadinya akut miokard infark dibandingkan wanita karena wanita memiliki hormon esterogen, dimana hormon esterogen tersebut melindungi dinding pembuluh darah dari lemak yang menyebabkan penyumbatan pada pembuluh darah (Hananto, 2006).

Berdasarkan hasil penelitian pada tabel 4.3 menunjukkan bahwa dari 30 responden yang didapatkan, mayoritas mengalami kecemasan sedang sebanyak 13 responden dengan presentase $(43,3 \%)$, kecemasan berat 10 responden $(33,3 \%)$ dan sedikit yang mengalami kecemasan ringan sebanyak 7 responden (23,3\%). Penyebab kecemasan terjadi adanya peristiwa traumatik yang berkaitan dengan krisis yang dialami, konflik yang tidak terselesaikan, terapi maupun medikasi serta kegagalan fisiologis (Suliswati, 2005). Kecemasan yang tidak terselesaikan dapat menimbulkan dampak fisiologis dan psikologis. Secara fisiologis kecemasan mengakibatkan palpitasi, jantung berdebar, tekanan darah tinggi, denyut nadi menurun, nafas cepat dan dangkal. Ditinjau dari psikologis menyebabkan kegelisahan, mudah tersinggung, khawatir, berperilaku menghindar dan penurunan konsentrasi (Jeffrey, Spencer \& Beverly;2005).

Dalam penelitiannya Gustad \& Laugsand (2014), mengemukakan bahwa kecemasan yang tidak tertangani sepenuhnya akan menyebabkan serangan ulang pada pasien akut miokard infark, sehingga dapat 
menyebabkan kecemasan yang timbul akan lebih besar dari yang sebelumnya. Berdasarkan hasil penelitian pada pada tabel 4.4 menunjukkan bahwa dari 30 responden yang didapatkan, mayoritas menjalani lama rawat sedang sebanyak 17 respondeng dengan presentase $(56,7 \%), \quad 13$ responden $(43,3 \%)$ menjalani lama rawat dan tidak ada responden yang menjalani hari rawat lama. Karakteristik responden berdasarkan usia rata-rata 51-65 tahun dengan jumlah 19 responden atau sekitar 63,3\%, bertambahnya usia seseorang dapat berpengaruh pada kesehatannya, dimana terjadi kemunduran struktur dan fungsi organ, selain itu juga dipengaruhi faktor emosional, sebagian jumlah orang tua dengan penyakit kronik akan mencemaskan keadannya, sehingga kesembuhan menjadi lama dan juga menambah perawatannya di rumah sakit (Gunarsa, 2008).

Pada penelitian ini didapatkan lama rawat pasien akut miokard infark adalah 2 hari dan terlama adalah 6 hari. Rata-rata pasien akut miokard infark menjalani lama rawat sedang 4-7 hari. Dalam penelitiannya Rosi \& Yertizal (2012) tidak jauh berbeda yang dilakukan di RSUP DR.M. Djamil Padang menyebutkan bahwa lama hari rawat inap penderita SKA berkisar 6-9 hari. Lama rawat pasien dengan gangguan fungsi jantung di RSU Tugurejo berkisar antara 1 hingga 5 hari ( Sarinti, 2007). Hal ini didukung oleh data rata-rata lama hari rawat pasien yang dirawat di ruang ICVCU RSUD Dr. Moewardi 3-5 hari (Rekam Medis RSDM, 2015). Menurut Heryati (1993, dikutip dalam Suheri, 2010), lama hari rawat merupakan salah satu unsur atau aspek asuhan pelayanan rumah sakit yang dapat dinilai atau diukur. Bila seseorang dirawat di rumah sakit, maka yang diharapkan baik oleh tenaga medis maupun oleh penderita itu sudah tercapai maka tentunya tidak ada seorangpun yang ingin berlama-lama di rumah sakit. Variasi lama rawat ini dipengaruhi oleh beberapa faktor antara lain keparahan penyakit, mutu pelayanan rumah sakit dan mekanisme koping, di dalam mekanisme koping keluarga sangat berperan, menurut Syamsiah (2012) menyatakan bahwa dukungan emosional keluarga sebagai tempat yang aman dan damai untuk istirahat dan pemulihan serta membantu penguasaan terhadap emosi.

Berdasarkan tabel $4.7 \quad$ Uji korelasi menggunakan Spearman menunjukkan hasil korelasi Spearman antara kecemasan dengan lama hari rawat dimana nilai signifikansi (p) 0.041 karena nilai $\mathrm{p}<0.05$ maka Ho ditolak artinya ada hubungan antara tingkat kecemasan dengan lama hari rawat, sehingga terdapat hubungan yang signifikan antara tingkat kecemasan dengan lama hari rawat. Hal ini mendukung hipotesis yang sudah ditegakkan oleh peneliti. Penyakit jantung khususnya akut miokard infark merupakan krisis kesehatan yang tidak dapat langsung terselesaikan, harus melalui progam perawatan yang berlangsung secara lama sehingga dapat menyebabkan kecemasan, progam terapi yang dilakukan pasien akut miokard infark bertujuan untuk memulihkan kondisi fisik, mental serta vokasioal (Muttaqin, 2009). Lama hari rawat pada pasien akut miokard infark yang berkelanjutan akan menimbulkan dampak psikologis dapat berupa kecemasan yang menyebabkan hipoksia pada jaringan otot jantung yang memaksa sel-sel melakukan 
metabolisme $\quad \mathrm{CO} 2, \quad$ sehingga menghasilkan asam laktat dan merangsang pengeluaran zat iriatif seperti histamin, kinin yang merangsang ujung-ujung saraf reseptor nyeri. Persepsi nyeri karena rangsangan saraf simpatis berlebihan akan meningkatkan beban kerja jantung meningkat (Corwin, 2008). Secara fungsional, akut miokard infark menyebabkan kontriksi dengan gerak dinding abnormal, terganggunya kepaduan ventrikel, berkurangnya volume denyutan, berkurangnya waktu pengeluaran dan meningkatkannya tekanan akhir diastole sehingga muncul tanda nyeri dada, sesak nafas, dan fatique (Tambayong, 2000). Hasil penelitiaan ini sejalan dengan teori yang dikemukakan oleh Utama (2003) dikutip dalam Udi (2010), lama hari rawat dapat mempengaruhi kondisi seseorang yang sedang dirawat. Sementara menurut Carrpenito (2007), kecemasan yang terjadi pada pasien dan keluarga juga bisa dipengaruhi oleh lamanya seorang dirawat.

Kecemasan bisa dirasakan bila individu mempunyai kepekaan lingkungan, klien yang baru pertama dirawat di rumah sakit dihadapkan pada situasi dan lingkungan baru sehingga kemampuan adaptasi klien akan mempengaruhi kecemasan. Menurut Utama (2010), kecemasan timbul akibat ketidakmampuan berhubungan interpersonal dan sebagai akibat dari penolakan.

\section{KESIMPULAN DAN SARAN}

Dari penelitian ini didapatkan Sebagian besar pasien Akut Miokard Infark (AMI) mengalami kecemasan tingkat sedang sebesar $43,3 \%$ dan berat sebesar $33,3 \%$ tetapi ada beberapa yang mengalami kecemasan ringan sebesar
23,3\%. Sebagian besar pasien Akut Miokard Infark (AMI) menjalani lama hari rawat sedang sebanyak 17 responden $(56,7 \%)$, lama hari cepat sebanyak 13 responden $(43,3 \%)$, dan tidak ada responden yang menjalani lama hari rawat lama. Disimpulkan ada hubungan yang signifikan antara tingkat kecemasan dengan lama hari rawat pada pasien Akut Miokard Infark (AMI) di Ruang ICVCU RSUD Dr. Moewardi dengan probabilitas 0.041.

\section{DAFTAR RUJUKAN}

Ade Sutrimo, (2014). Pengaruh guided imagery and music (GIM) terhadap kecemasan pasien pre operasi SC di RSUD Banyumas (diakses 22 Januari 2016).

Arikunto, S. (2010). Prosedur Penelitian. Jakarta : Rineka Cipta

Barbara J, Billie F., Brahm Pendit (2006). Buku Ajar Perawatan Perioperatif. Volume 2. Jakarta. Penerbit Buku Kedokteran EGC

Carpenito, L.J (2007). Buku Saku Diagnosis Keperawatan Edisi 10. Jakarta : Buku Kedokteran EGC

Corwin, E. J. (2009). Buku Saku Pathofisiologi. Jakarta : EGC

Departemen Kesehatan RI (2005). Standar Pelayanan Minimal, Direktorat Jendral Bina Kesehatan Masyarakat. Jakarta

Fema Solekhah B. (2009). Mutu Pelayanan Kesehatan, Prepektif Internasional. Penerbit Buku Kedokteran, EGC

Fitriyanti, (2008). Faktor-faktor yang mempengaruhi kecemasan pasien dalam tindakan kemoterapi di RS Dharmais 
Jakarta. (diakses 20 januari 2016)

Gunarsa S. (2008). Psikologi Perawatan. Jakarta : Gunung Mulia.

Gustad, L.T \& Laugsand, L.E. (2014). Symptoms of Anxiety And Depression And Risk Of Acute Miocardial Infarktion. www.medscape.com. (diakses 22 Februari 2016).

Hananto, A. (2006). Penyakit Kardiovaskuler. Jakarta : EGC

Hidayat, A.A.A. (2009). Metode Penelitian Keperawatan dan Teknik Analisis Data. Jakarta. Salemba Medika

I Ketut Maendra, (2014). Pravalensi Tingkat Kecemasan pada Pasien Infark Miokard di Poliklinik Jantung RSUP. Prof. Kandao Manado. (diakses 20 Februari 2016).

Imbalo S Pohan (2007). Jaminan Mutu Layanan Kesehatan. Penerbit Buku Kedokteran EGC. Jakarta

Indradi, Rano. (2007). Antara Lama dan Hari Perawatan. www.ranocenter.net diakses 28 Desember 2015

Jacobalis S (2000). Beberapa Teknik dalam Managemen Mutu. Managemen Rumah Sakit. Gramedia Widiasaranan Indonesia. Jakarta.

Jeffrey, Nevid dkk. (2005). Psikologi Abnormal Jilid 1. Jakarta : Erlangga.

Jos Ridi, (2012). Jurnal Penelitian Hubungan Status Sosial Ekonomi dengan Tingkat Kecemasan. RSUD. Cilacap. Jtstikesmuhgo-gdlcas-josridi1467-1-bab1-3-o(1).pdf (diakses 19 Januari 2016)
Keliat, B.A dkk. (2005). Managemen Kasus Gangguan Jiwa. Jakarta : Buku Kedokteran EGC

Kusyahardi, (2005). Hubungan kecemasan dengan koping maladaptif pada pasien dengan infark miokard akut. Yogyakarta. (diakses 20 Januari 2016).

Maramis. (2009). Catatan Ilmu Kedokteran Jiwa. Edisi 2. Surabaya: Airlangga

Meana, M \& Lieberman,L. (2009). Cardiac rehabilitation : Gender Differences In Factors Influencing Partipation. http://online.liebertpub.com. (diakses tanggal 8 Februari 2016).

Morton, P. G., Fontaine, D., Hudak, Carolyn M., Gallo, B. M. (2011). Keperawatan Kritis Pendekatan Asuhan Holistik Volume 1. Jakarta : Buku Kedokteran EGC.

Muttaqin, A. (2009). Asuhan Keperawatan Klien Dengan Gangguan Sistem Kardiovaskuler dan Hematologi. Jakarta : Salemba Medika

Nursalam. (2014). Konsep dan Penerapan Metodologi Penelitian Ilmu Keperawatan Pedoman Skripsi, Tesis, dan Instrumen Penelitian Keperawatan. Jakarta: Salemba

Pantee, B \& Hungler, B.P. (2011). Review : Anxiety and Quality of life in patients with Miocardial Infarction.

http://ejournal.undip.ac.id. (Diakses tanggal 8 Januari 2016) 
Revans Regenal (2004). Research Into Hospital Management and Organization. Health Servise Research Study Section of the United States Public Health Servise. New York

Rosi, O., Yertizal, K., Zulkarnain, E. (2012). Hubungan Kadar Glukosa Darah Saat Masuk Rumah Sakit Dengan Lama Hari Rawat Pasien Sindrom Koroner Akut (SKA) di RSUP Dr.M. Djamil Padang. www.jurnal.fk.unand.ac.id/inde x.php/jka/article. (diakses 10 Februari 2016).

Sarguna, Listiani. (2004). Organisasi Manajemen Rumah Sakit. Konsorsium Rumah Sakit Islam Jawa Tengah dan Yogyakarta.

Saryono. (2010). Kumpulan Instrumen Penelitian kesehatan. Yogyakarta : Mulia Medika.

Sarinti. (2007). Hubungan Jenis Penyakit Dan Tingkat Kecemasan Dengan Lama Rawat Pada Pasien Gangguan Fungsi Jantung di Ruang ICCU RSU Tugurejo Semarang. http://digilib.unimus.ac.id/files/ disk1/2/.com. (diakses 10 Januari 2016).

Setiawan I \& Sulastri. (2008). Hubungan Perawatan dengan Motivasi Kebutuhan Seksual Laki-Laki Usia 21-55 tahun di Rumah Sakit Umum Islam Kustati Surakarta. Berita Ilmu Keperawatan Vol. 1 No. 4. (diakses 11 Desember 2015).

Smeltzer, S.C. dan B.G. Bare. (2011). Buku Ajar Keperawatan Medikal Bedah Brunner \& Suddart. Edisi 8. Jakarta: EGC

Stuart dan Sundeen. (2002). Buku Saku Keperawatan Jiwa Edisi
3 alih bahasa Achir Yani. S. Jakarta: EGC

Suheri. (2010). Gambaran Hari Lama Rawat Dalam Terjadinya Luka Dekubitus Pada Pasien Immobilisasi Di RSUP Haji Adam Malik Medan. http//www/respiratory.usu.ac.id. (diakses 9 Februari 2016).

Sugiyono. (2011). Metode Penelitian Kualitatif, Kuantitatif dan $R$ \& $D$. Bandung: Alfabet

Suliswati. (2005). Konsep Dasar Keperawatan Kesehatan Jiwa. Jakarta : EGC

Syamsiah, (2012). Petunjuk Modern Kesehatan Keluarga. Panji Pustaka : Yogyakarta

Tambayong, J (2000). Patofisologi untuk Keperawatan. Jakarta : Buku Kedokteran EGC

Videbeck, S.L (2008). Buku Ajar Keperawatn Jiwa. Jakarta : Buku Kedokteran EGC

Walgito, B. (2001). Psikologi Social Suatu Pengantar, Penerbit Andi, Yogyakarta.

Yuliyanti \& Cecep. (2012). Gambaran Kualitas Hidup Pasien Acute Coronary Sindrome di Poliklinik Jantung Rumah Sakit Al Islam Bandung. http://jurnal.unpad.ac.id/ejourna 1/article. (diakses 8 Februari 2016). 